Notre Dame Law School

NDLScholarship

Natural Law Forum

$1-1-1962$

\title{
Toward a Thomistic-Anthropological View of the Evolution of Obligation
}

Charles Fay

Follow this and additional works at: http://scholarship.law.nd.edu/nd_naturallaw_forum

Part of the Law Commons

\section{Recommended Citation}

Fay, Charles, "Toward a Thomistic-Anthropological View of the Evolution of Obligation" (1962). Natural Law Forum. Paper 71. http://scholarship.law.nd.edu/nd_naturallaw_forum/71

This Article is brought to you for free and open access by NDLScholarship. It has been accepted for inclusion in Natural Law Forum by an authorized administrator of NDLScholarship. For more information, please contact lawdr@nd.edu. 
TOWARD A THOMISTIC-ANTHROPOLOGICAL VIEW OF THE EVOLUTION

\section{OF OBLIGATION}

\section{Charles Fay}

The central contention of this paper is that an ethic which is both Thomistic and evolutionary is an intrinsic possibility and that the Thomist philosopher will necessarily adopt an evolutionary standpoint if he actually confronts the results of the contemporary science of anthropology. An analysis of obligation and the theory of moral determinants in Thomism reveals that any factor which modifies human tendencies is potentially a moral determinant; and if the factors which modify human appetites can be studied fruitfully from the point of view of bio-cultural evolution, so also can human obligation.

The contemporary scientific study of bio-cultural evolution shows that those human urges and needs which lie at the base of the natural law and of every judgment of value are themselves transformed by the evolutionary process. On the one hand we find in St. Thomas's analysis of natural law, obligation, practical reason, and the cardinal and associated virtues, insights whose perennial value is demonstrated through explaining on the philosophical level what anthropologists know empirically concerning the universal features of moral experience. On the other hand, the doctrine concerning the nature of justice and its essential divisions as found in the Summae Theologiae cannot be applied without essential revision to the primitive mode of living as this is disclosed by prehistory and comparative studies of primitive cultures. Nor can this doctrine be applied univocally to the agricultural state and the emerging world society. It is possible to formulate a catholic ethics based upon needs analogously common to all humans only in the light of an understanding of what is in actual fact universal and what is variable in the human situation.

\section{The Relation of Anthropology to Philosophy}

ONE OF THE characteristics of culture is that it embodies value. Hence from the point of view of anthropologists, their science has much to contribute to ethics. Recently a bibliography was brought out by several anthropologists, and a survey of the approximately 2,000 items establishes the overlapping of ethics and the empirical sciences of man at least during the 
period 1920-1958. 1 It was in fact precisely the need for a research instrument on the part of those interested in cross-disciplinary work which led to the construction of a representative selection from the more than 7,000 items of material they considered.

Some moral philosophers have also discovered the relevance of the empirical sciences and particularly anthropology. Abraham Edel has a general study of the substantive contributions of the biological, psychological, and social sciences to ethics, and has also written on anthropology and ethics. ${ }^{2}$ MacBeath studied ethnographic materials to work out the concrete interrelation of operative ideals and social structure in four primitive cultures. ${ }^{3}$ R. B. Brandt made a number of field trips to the Hopi in order to secure data of special interest to philosophers concerning the goals, attitudes, and concepts of the Hopi cultural system. ${ }^{4}$ John Ladd developed a general theory of descriptive ethics and illustrated it by a hypothetical reconstruction of the ethical system implicit in the ethical discourse of the Navaho Indians. ${ }^{5}$ According to Clyde Kluckhohn, Ladd's professional training as a philosopher enabled him to expand the ethnographic knowledge of the Navaho. Ladd's informant (a kind of professional Navaho casuist) said to Kluckhohn: "I have been trying to explain these things to you for thirty years, but you never asked me the right 'questions."6

Philosophy and anthropology are vast areas of research and study with many problems in common. The philosophers just mentioned are interested chiefly in the study of moral orders, their concrete interrelations with culture and their inner logic, and the problem of moral absolutes and cultural relativism. How does philosophy in the tradition of Aristotle and St. Thomas relate itself to the kind of data offered by anthropology? Let us consider from the viewpoint of this philosophical tradition two large areas of anthropology, dealing with the concept of culture and with the data of evolution.

The notion of culture in technical anthropological usage is a broad, flexible (analogous) concept which can be employed by prehistorians and students of society to integrate on an empirical level all the data and theory concerning the manifold and divergent lives that humans have lived in

1. Ethex M. Albert \& Clyde Kluckhohn, A Selected Bibliography on Values, Ethics, and Esthetics in the Behavioral Sciences and Philosophy, 1920-1958 (1959). The behavioral sciences include anthropology, psychology, sociology, political science, economics.

2. Abraham Edel, Ethical Judgment (1955); May \& Abraham Edel, Anthropolooy AND EThics (1959).

3. A. MacBeath, Experiments in Livino (1952).

4. Richard B. Brandt, Hopi Ethics (1954). See also Brandt's Ethical Theory ch. 5

(1959) for his views on the relationship of philosophy and anthropology.

5. John Ladd, The Structure of a Moral Code (1957).

6. Clyde Kluckhohn, Foreword to LADD, op. cit. supra note 5, at xiv. 
groups throughout the social continuum from savagery to civilization. Although rejected by some scientists as too broad and tinged with valuation for scientific discourse, this cardinal concept is "one of the key notions of contemporary American thought. In explanatory importance and in generality of application it is comparable to such categories as gravity in physics, disease in medicine, evolution in biology."7

In 1917 Kroeber published an essay entitled "The Superorganic" in which he gave reasons for designating culture as more than organic. ${ }^{8}$ The contemporary scientist lacks a concept of the spiritual and consequently is unable to cope with the superorganic aspects of culture, so that what constituted for Kroeber difficulties in the "superorganic" remain to this day without solution. But this superorganic character of culture should be of great interest to the Thomist who wishes to demonstrate the spiritual nature of man by using contemporary materials and the current concepts of science.

In the domain of physical anthropology we find material relevant to morality and a philosophy of man. The fossil evidence of extinct forms of man has led scientists to include man within the evolutionary tree of life. To summarize contemporary findings and theory in the light of Thomistic concepts: An abundance of fossil material of zoological types other than homo sapiens has been found definitely associated with artifacts which could only be the effect of a rational animal. Both the bones and the tools are sufficiently uniform or standardized that we can say of the one that the morphological characters breed true and of the other that they are the effect of a tool-making animal with an abstract concept of the tool he makes which he communicates to others as part of a tool-making tradition. This data arguably indicates the existence early in the Pleistocene of rational animals (as understood in Thomistic philosophy) that are ancestral to but distinct both in morphology and behavior from homo sapiens (as understood in evolutionary taxonomy). ${ }^{9}$ The slow pace of early technological evolution, coupled with a brain less than half the size we currently possess in some instances, suggests that there are solidly probable grounds for regarding such an animal as exercising powers of native intelligence which are much more limited than those we know today. A reason limited in the

7. A. L. Kroeber \& Glyde Klugkhohn, Culture: A Grtichl Review of Concepts AND Definitions 3 (1952).

8. A. L. Kroeber, The Superorganic, reprinted in A. L. Krogber, The Nature of Culture (1952).

9. For a survey of the empirical evidence concerning human evolution, see Sor TAx, ed., Evolution After Darwin, Vol. II, The Evolution of Man (1960). Shorter summaries are found in G. W. Lasker, The Evolution of MAN (1961), and in J. N. Spurler, ed., The Evolution of Man's Capactity for Culture (1959). 
practical order of toolmaking would also be limited in the practical ordering of human actions, so that the exercise of acts of prudence would be carried out less perfectly.

A Thomist can hardly consider the implications of evolution and genetic change without relating it to his metaphysical explanation of the individuation of the human soul by determined matter. That is to say, if the human genotype shifts in the course of history, so does the matter which individuates the human soul. When the DNA molecules within the nucleus of the sex cells change, there is an alteration of the matter constituting the human body down to the molecular level. Doubtless, the genetic code of the DNA molecule according to the Crick-Watson model has only the most circuitous relation to what the Thomist knows as signate matter; yet such a relationship does exist however roundabout, with the result that it is contradictory to say that (a) heredity changes and also (b) the matter in which the soul is received and which limits it is unaltered by this change. The philosophical account of individuation I regard as certain and the anthropological data as highly probable. The conclusion I draw is that the mode or manner of existence of the human soul within the zoological type homo sapiens is probably different from, say, Sinanthropus-Pithecanthropus or the Australopithicinae. These differences are no doubt accidental from the point of view of man's common human nature. Nevertheless, they are of a type which would make all humans presently in existence different from at least some of their ancestors in the Ice Ages and they probably have some bearing upon even the exercise of acts of deliberation, judgment, and command in the moral order.

This conclusion, that all humans presently in existence differ from at least some men of the Ice Ages in ways that are relevant to the human exercise of moral acts, could not have been drawn independently of the discoveries of contemporary anthropologists and other scientists. And while undoubtedly philosophers have always been aware of cultural diversity marking off one group from its neighbors, the extent of variability as well as the presence of certain common characteristics has not been so well documented nor investigated scientifically. More than ordinary experience is required to say that the common nature of rational animal is not only incompletely realized in the multiplicity of individuals who coexist but further that the virtualities and potentialities implicit in this nature are realized to a variable extent in different stages of human history. ${ }^{10}$

Traditionally, Western philosophers have taken as their starting point

10. See J. Franklin Ewing, S.J., What About Evolution? 58 Catrourc Mrnd 388 (1960). 
evidence from ordinary experience. This data from immediate experience is examined reflectively within the context of problems and solutions of a developing philosophical system. Change is a fact of experience and so also is the plurality of beings about us. The philosopher, however, looks at these facts differently from the man of common sense. He regards them from the viewpoint of their being and he considers the problems that both a change in being and a multiplicity of beings pose. He studies being inasmuch as it exists, or he seeks an understanding of human nature by analyzing man's distinctive mode of action, or in ethics he investigates the manner in which human acts are ordered to man's proper good. The approach of the scientist is quite otherwise. He establishes his results by an empirical method of considering phenomena qua predictable rather than qua existent. Hence a great deal of contemporary science is irrelevant to the questions that have engaged Western philosophers in the past. However, it would be very strange indeed if among the many studies now labeled scientific some new data did not arise which cast fresh light on the way beings actually exist and operate. By situating some of these findings within the framework of a philosophical tradition, they are placed in a new epistemological and metaphysical system in which philosophical reflection may extend our knowledge of real beings. As the ordinary experiences of motion and diversity presented problems in the context of early Greek philosophy, so today new intelligibilities result when the scientific study of culture and evolution is related to perennial philosophical positions.

\section{The Openness of Thomistic Ethics to Anthropology}

For ST. Thomas the experience of obligation is implicit in the practical knowledge that an act is desirable or that an act is necessary to realize a good appropriate to man in virtue of certain appetites rooted in human nature. This is a need theory of value. It is developed in a metaphysical context which considers the tendencies of the moral agent as ordered to the conservation and expansion of its own being. The actuality or perfection of existence is desirable when it is related to appetite; that is, being considered as an object of tendency is good. Every being necessarily seeks its own perfection, and viewed metaphysically this tendency means that every being seeks to conserve and expand its existence. Ultimately, this seeking is the creature's tendency toward God, its inclination toward imitating the divine nature; and in seeking to maximize his own existence, man achieves his own perfection through imitating in however diminished a manner God 
Himself. Proximately and immediately, this fullness of being consists in the satisfaction of dynamic tendencies ranging from psycho-biological urges (inherited from chordate and mammalian ancestors) to superorganic needs which are communicated to matter once it has been sufficiently disposed and elevated by the evolutionary process for the reception of the human soul.

The eternal law or the divine reason and Author of all nature is unchangeable. This truth is no doubt the ultimate explanation of why there are unchangeable aspects of the law based upon human nature. ${ }^{11}$ Considered as a divine idea, human nature is unchangeable in every way; considered in rerum natura, it has a concrete existence in which necessity coexists with mutability. Human nature is necessarily rational, animal, free, risible; nevertheless in its concrete existence it is also mutable, and it is mutable in ways which are ethically significant. The understanding man has of his obligation is not found in him in the same way that knowledge of human obligation is present in God as an eternal exemplar. "Whatever is received in another is received according to the nature and mode of being of the recipient." This Thomistic axiom might well be borne in mind in elucidating the sense in which the natural moral law in man is a participation of the eternal law. The norm of human action as present in human experience is limited by an intellect which is incarnate, which exists in time, and which knows what is suitable through the human person's experience of rational and sentient needs.

The experience of pan-human needs by human agents who exist in time is subject to all the limitations of such a mode of being. It is not simply that practical understanding of the universal requirements of human nature grows in time, but there is an evolution of institutions and conditions which alters the way human life is actually carried on and which transforms the obligations humans experience in the light of their natural desires. Any factor that influences the fulfillment of human tendencies in the concrete may be viewed as a moral determinant. These determinants are related differently to human nature and its needs in different stages of human history.

St. Thomas recognizes three classes of moral determinants which specify the moral quality of human action: the object, the end, and the circumstances. ${ }^{12}$ The moral obligation of a mother to take care of her children, for example, is deeply rooted in human needs, biological, psychological, and social. ${ }^{13}$ If any bio-social needs have an absolute structuring effect upon

11. Summa Throloonaz, I-II, 97, 1, ad 1. (This work will hereafter be cited as S.T.)

12. S.T., I-II, 18, articles $2,3,4$.

13. MAY Edel \& Abraham EDel, op. cit. supta note 2, at 34-43. 
morality, surely this one must. In the technical terminology of St. Thomas, such acts of the mother as feeding the child, protecting him from harm, teaching him the difference between right and wrong, are actions which are good in their object. The object of an act is understood to be the primary and essential source of its goodness in a manner analogous to the way the substantial form of a natural thing is the source of its being. The object is to be distinguished from the end of the agent, the good which he understands to be present in an action and which incites him to act. The end is either due or not, suitable or not, in the light of a holistic consideration of the situation and man's needs.

Just as accidents also contribute to the fullness of being due to a natural thing through modifying its being, the circumstances which in the concrete "touch" a human act and alter its bearing upon human needs also change its moral goodness in an accidental sense. Sometimes St. Thomas employs the term "circumstance" in a broad way to include conditions essential to the object of an action, conditions consequently which determine the specific character of good and bad acts inasmuch as they have a special significance in relation to right reason.14 Stealing from a sacred place, for instance, adds a new contrariness to reason, above and beyond that already involved in theft. Place is always an accident in relation to the speculative consideration of a nature which prescinds from concrete determinations arising from time and place. But what is of accidental or essential significance concerning the goodness or badness of human action is a problem in the area of practical reason. St. Thomas's recognition that what is accidental in one instance may be the essential condition of a new type of moral action in another suggests that his theory is open to the view that variations in the symbolic significance of actions that are cultural in character may also essentially diversify human actions.

In a study of practical reason in Thomistic theory, Naus says that custom constitutes a factor which specifies secondary precepts of natural law. He goes on to say:

.. . custom is not something arbitrary but rather an adaptation which a people make (ideally according to right reason) to the circumstances in which they find themselves. ". . . for custom is in a way changed into nature and produces an inclination similar to a natural one." [S.T., I-II, q. 58 a. 1, c.] If these customs which determine native tendencies are reasonable, then the fixed pattern of activity they prescribe becomes "connatural."15

14. S.T., I-II, 18, 10, c., ad 1.

15. John E. Naus, S.J., The Nature of thr Practical Intrllect accordino to SAint Thomas Aquinas 56-57 (1959). 
If we use the concept of culture instead of custom, we can develop St. Thomas's ethics in a way that is in harmony with its inner dynamism while at the same time introducing a more profound and far-reaching relativity than St. Thomas contemplated. The concept of culture includes not merely behavior which is "appropriate" or socially sanctioned but all socially shared experiences and behavior which is founded upon learning. St. Thomas apparently does not include human law within the notion of custom when he says that "custom has the force of a law, abolishes law, and is the interpreter of law"; ${ }^{16}$ whereas culture includes both the human law and its customary interpretation. Culture explicitly includes technology, social structure, economic organization, ethos and world view, factors which are related to human needs and which, from the point of view of the moral agent, have profound effects upon the meaning of human action. If we consider the "within" of an action, these factors introduce extensive variability into what is naturally right for man. The use of culture rather than custom makes available to the ethician a vast and growing body of data concerning the extent and limits of this variability.

Nor can the partial truth of cultural relativism be assimilated into a Thomistic ethics by reducing the impact of culture on human needs to the traditional category of circumstances (considered merely as accidental in relation to right reason), for culture is a variable element in each of the three determinants-object, end, and circumstances. We shall see in the next section that the very nature of justice and its logical divisions into common legal and particular justice, and particular into distributive and commutative justice, are quite different on the level of primitive and of civilized society.

Some range of development is admitted by St. Thomas himself in granting the possibility of adding to natural law while denying that obligations under the primary precepts may be subtracted. ${ }^{17}$ One of his examples of rights added to natural law is property rights, which St. Thomas classifies as pertaining to ius gentium and which we would today regard as part of natural law. In several places he goes further to note a concrete variability in man's nature which alters natural rights. ${ }^{18}$ Moreover, some of the reasons he gives

16. S.T., I-II, 97, 3, c.

17. S.T., I-II, 94,5 , c.

18. . . natura humana non est immobilis sicut divina; et ideo diversificantur ea quae sunt de jure naturali; secundum diversos status et conditiones hominum. In IV SENT., d. 26 , q. 1 , a. 1 , ad 3 .

.. propter diversas hominum conditiones contingit quod aliqui actus sunt aliquibus virtuosi, tamquam eis proportionati et convenientes, qui tamen sunt aliis vitiosi, tamquam eis non proportionati. S.T., I-II, 94, 3, ad 3.

... illud quod est naturale habenti naturam immutabilem, oportet quod sit semper 
to justify change in human law also apply in the case of natural law. ${ }^{19}$ Thus it seems natural for human reason to advance gradually from the imperfect to the more perfect in regard to natural law as well as positive. Man makes natural progress in the exercise of speculative reason; so also growth in human understanding in the practical order seems possible even in regard to what is suitable to needs shared in common by all humans. If the changed conditions of civil society require some variation in positive law, it seems reasonable to hold an analogous variation in natural obligations insofar as the human situation is altered. However, the evolution here proposed is offered as a development of Thomistic thought rather than as a proposition formally taught by St. Thomas.

Human law may be derived from natural law in two ways: as a conclusion (ius gentium) from a premise, or by determining certain generalities in natural law. ${ }^{20}$ As an example of a general obligation that is subject to further determination, St. Thomas says it is a matter of natural law that evildoers should be punished. But that they be punished in this way or that way is a determination of the law of nature. This portion of human law is technically designated ius civile and it is a reasonable determination of natural law in the light of the special history and culture of each state.

From my own point of view, I would recognize one kind of natural right or duty which is so immediately connected with human nature that the right or duty inheres in all humans in every society and in every time - for instance, the right of all adult humans to marry; the obligation of parents to care for and educate their children. From this kind of right or duty may be distinguished others which are also necessary for satisfying human needs but only on a certain cultural level. These do not express necessities which obtain cross-culturally but are suitable to human nature at a particular stage of social evolution. The rights which fall under ius gentium are for the most

et ubique tale. Nature autem hominis est mutabilis. Et ideo id quod naturale est homini potest aliquando deficere. S.T., II-II, 57, 2 ad 1.

The difficulty arises that these changes in the states and conditions of man are extrinsic to the nature of man and that the cultural changes that have occurred since, say, the Middle Ages are also "outside" or peripheral to man. It is true that such changes are extrinsic to man's common human nature as this is understood in human knowledge by an act of abstraction; from this viewpoint even the organic changes which occurred during the Pleistocene and which shaped a body more subservient to the needs of the spirit were similarly extrinsic. However, the base of evaluation is man's concrete nature. If we consider human nature as it actually exists, such changes are intrinsic to man and directly influence what is suitable to human appetites. That is, these changes are intrinsic to human nature considered as concretely related to material beings, to other humans, and to God, and the natural law inasmuch as it is a function of practical reason is based upon human nature so considered.

19. S.T., I-II, 97, 1, c. and ad 1.

20. S.T., I-II, 95, 2. 
part of this character. Consequently, if an evolution occurs in human institutions and in ius gentium, then we must accept at least limited evolution in natural law.

\section{Justice in St. Thomas and in Primitive Society}

Justrce Is A HABIT which inclines the individual to will the good which is due to another. It orders external actions insofar as they affect society or another individual. In St. Thomas's treatment, justice is divided into common legal justice which is concerned with the good of society, and particular justice whose object is the particular good of another person. ${ }^{21}$ This division pertains to the very essence of justice, and it presupposes the existence of political organization. Particular justice in turn is subdivided into two types, depending on whether the good due to another is his share of the common good of a community (distributive justice) or is simply due to him from someone's private resources (commutative justice). ${ }^{22}$ Commutative justice aims to establish an equality of thing with thing, and this is not affected by the relationship of the persons involved, that is, whether they are relatives or what their rank or status may be in the community.

The right or the just which is the peculiar object of justice is distinguished into two parts, natural and positive, depending upon whether the objective equality which justice seeks in human relations is determined by the nature of the situation or results from some agreement among men. ${ }^{23}$ Given the human situation, it is necessary that parents educate their offspring. This is naturally right; it does not result from some free agreement in a human society but is necessarily imposed upon the human will by the intellect's understanding of what is essential for the common welfare of the family. The right price of a painting, on the other hand, is determined largely by private bargaining; the amount of tax on income is established by the decision of some legislative body. There is still a third kind of right arrived at by civilized societies independently of one another and explicitly defined in their oral or written legal codes - the ius gentium, which also seems to be in some sense natural. An example: the rights and duties connected with the use and management of material things.

St. Thomas's doctrine on property is rather complex. ${ }^{24}$ All humans have a right to use the goods of this earth; otherwise life and the reasonable fulfill-

21. S.T., II-II, 58, 5 and 7 .

22. S.T., II-II, 61, 1.

23. S.T., II-II, 57, 2.

24. See Vernon J. Bourke, Ethics 366-395 (1951). 
ment of human nature would be impossible. But in order that things may be of human use and may actually satisfy human needs, some system of holding and managing them must be devised for the common welfare of men. Inasmuch as man is a rational animal, he exercises by nature a dominion over material things; and the ultimate purpose of this management is the ordering of material goods for human use. It is important to realize that natural dominion is not identical with private possession, for goods may be held in common and managed by those in charge of the group, and such a system may sometimes be eminently suitable to the needs of human nature in particular cultural conditions.

Now let us see if we can apply St. Thomas's distinctions on the level of the simplest human society. In order to do this, it is not necessary to attempt a speculative reconstruction of life during the Ice Age. In isolated parts of the world, humans have continued to exist in ecological, social, and cultural systems which approximate (in some respects certainly and in others probably) the human situation prior to the invention of agriculture. The sociocultural life among the Shoshonean Indians of the Great Basin of the western United States illustrates an essentially family level integration:

It is perhaps difficult to imagine that a family, alone and unaided, could obtain virtually all the food it consumed; manufacture all its clothing, household goods, and other articles; rear and train its children without assistance; take care of its sick except in time of crisis; be self-sufficient in its religious activities; and, except on special occasions, manage its own recreation. Why this was so in the case of the Shoshoneans is explainable largely in terms of their cultural ecological adaptations.

Owing to the nature of the natural environment of the Great Basin area and to the simple hunting and gathering techniques for exploiting it, it was inevitable that the individual family or at the most two or three unrelated families should live in isolation during most of the year. "Family" in this case signifies the nuclear, biological or bilateral family, consisting of mother, father, and children. Unlike many primitive peoples, the Shoshoneans were not organized in extended family or lineage groups . . . the functioning unit was the nuclear family, augmented only by a grandparent, aunt, or uncle who otherwise would be homeless. ${ }^{25}$

Loose aggregates of comparatively independent families like the Shoshoneans occur rarely; however, they illustrate the extreme variability of what is naturally right. The Shoshonean concept of property rights was directly related to their mode of life. Anything resulting from individual work or habitual use belonged to that individual, but for the most part the natural 
resources of the area were available to anyone on a "first come, first served" basis: ${ }^{26}$ Anyone could gather seeds, any family could fish in rivers and streams; but the food gathered or the artifact made belonged to whoever gathered or made it. Had families been excluded from certain territories, starvation and death would have followed. A system of private possession of the resources would have been essentially contrary to human nature as concretely constituted under these social and ecological conditions. Even groups of families did not exercise common possession, nor did the same families constitute a stable social community. Both the groups of families and the group leadership constantly changed. Families occasionally cooperated in the collective hunting of rabbits, with experienced men or "rabbit bosses" directing the activities. However, no stable territorial groups of fixed membership were established by such means. The drives were held only when rabbits were sufficiently numerous, involved only those families who happened to be in the locality, and took place only if some experienced leader happened to be present:

Since the occurrence of these factors was rather haphazard, since the place, the participants, and the leaders were never quite the same in successive years, the drives provided only temporary bonds between independent families. A given family was under no obligation whatever to participate in a drive with a fixed group of families under a permanent leader. And, since the "rabbit boss" held authority only during the drive, the family paid little heed to him in other times, places, and contexts. ${ }^{27}$

It is clear that on this level of Shoshonean society prudence and justice are exercised and rights must be respected. Even property rights exist. ${ }^{28}$ But the meaning of rights and obligations differs essentially from their meaning in societies with more developed social organization and some political organization. Under the conditions just described, the individual Shoshonean owed no debts under common legal justice to any leader or to any definite social group. There were no territorial rights to be defended, no military honors to be awarded, no means of organizing for concerted action:

Disputes and hostilities arising from such matters as murder, theft, wifestealing, and other violations of custom were settled between families. None of these was a "crime" against the community, for the community

26. Id. at 107 .

27. Id. at 110 .

28. See Stephen C. Cappannari, The Concept of Property among Shoshoneans, in Gertrude E. Dole \& Robert L. Carniero, eds., Essays in the Science of Culture (1960), for a discussion of property among the Shoshoneans and a brief discussion of various kinds of property. 
did not exist in any corporate or legal sense. Violations of custom threatened families, not larger socially integrated units. Thus, the very concept of crime presupposes some kind of suprafamily level of integration, some collectivity, which has a common purpose that must be protected against antisocial behavior by its members. ${ }^{29}$

What can be the meaning of distributive justice here? It could only be exercised within the nuclear family, and in the opinion of St. Thomas prudence and justice within the domestic group differ essentially from the virtues required in the distribution of goods belonging to civil society. ${ }^{\mathbf{3 0}}$

The Shoshonean example is admittedly an extreme one. The common human needs for mutual aid and friendship, for cooperation in subsistence and other activities, ordinarily lead to the association of families in bands, and bands may then federate loosely into tribes. To the extent that band organization obtains, there is some kind of common good associated with it which places obligations upon the individual. But in many bands, civil society does not exist; hence the good in question is not what St. Thomas had in mind in the definition of common legal justice. His definition presumes institutions whereby legislative, judicial, and leadership functions are exercised in view of the common good, where human law exerts a moral constraint upon the citizens of a political society, and where the bonds of association extend beyond kinship. But clans and tribes are intermediate forms of social organization which have not yet attained the level of civil society; that is, education, punishment for crime, warfare are left to the initiative of family groups.

An evolution occurs in community life and consequently in the meaning of the common good when effective political organization is achieved. Once this is attained, human lawmakers can legislate in view of the common good which unites an entire community and which permits a fuller development of human nature in that society. Both rulers and citizens exercise the virtue of general legal justice insofar as they respect what is necessary for the common good of the whole. Prior to political organization, however, there are no individuals who can speak with authority in the name of the whole community, distribute civil goods, allocate honors and responsibilities. Role and status are comparatively undeveloped, and relationships between persons are governed principally by age, sex, and kinship. In St. Thomas the notion of rank or status is essential to distributive justice, for a person 
receives more of the common good according to his more prominent position in the community. 31

If we find only rough analogues of distributive justice in primitive society, it does not follow that the justice practiced is therefore commutative. Commutations are exemplified chiefly in buying and selling, in which one individual pays another as much as he has received from him. St. Thomas argues that buying and selling seem to be established for the mutual advantage of both parties, each of whom requires something belonging to the other. "Whatever is established for the common advantage should not be more of a burden to one party than to another, and consequently all contracts between them should observe equality of thing with thing."32 Such considerations do not apply directly and without qualification to the economic and social orders in most primitive societies, where the relationship between goods or things depends upon and expresses the relationship between the persons involved. ${ }^{33}$ This is not to say that the value of goods is entirely ignored in every nonliterate society but that their value is subordinate to human relations. In a society based upon kinship, attention focuses primarily on the relationship of the parties to the transaction rather than upon the equality of thing with thing. Hence it is altogether misleading to think of justice in a primitive society based on kinship ties in terms of St. Thomas's distinctions.

\section{Conczusion}

WE haVE here used certain anthropological material to illustrate ethical development. With political integration humans learn to perceive in fellow citizens other persons who share rights and duties in a community comprised of individuals most of whom are not relatives by either real or fictive ties of consanguinity or affinity. Political unification greatly increases the all-around adaptability of society and safeguards tranquility against both internal and external enemies. Such unification provides a broader base of cooperation for meeting material needs and for fulfilling the higher needs of human personality. To the extent that there have now come into existence political and economic institutions that unite nations into larger regional groups, and to the extent that the United Nations may eventually develop into a world-wide political institution having power with regard to global problems, the kind of evolution that occurred in the meaning of

31. S.T., II-II, 61, article 2, c.

32. S.T., II-II, 77, article 1 .

33. Lesle A. White, The Evolution op Curture $244-46$ (1959). 
the common good and general legal justice at the time of the agricultural and urban revolutions is going on today. It is now possible for undeveloped countries to place claims under legal justice which are binding upon the whole world, but in a manner which is proportionate to the wealth and economic development of the more fortunate countries.

An evolution in justice could not occur without a corresponding development in the cardinal virtue of prudence. If human existence is altered through transformations in human society and economy and culture, alterations necessarily occur in the kind of right thinking concerning what should be done. In more advanced countries, new species of prudence come into being; the nonexistence of these moral species on simpler human levels must be considered a negation and not a privation. Today, men self-consciously assume the role of innovators in the social sphere as well as in technology and attempt to order bio-cultural evolution in a direction which would permit a fuller human life for all mankind; such persons would seem to exercise a new and formally different kind of prudence from anything discoverable concerning man in the Pleistocene Era. Thus in regard to prudence, the principle of all natural moral virtue, it would appear that some kind of evolution has taken place in the course of human history.

This development of human obligation in terms of justice and prudence implies both continuity and progress in the moral life. The fullness of being which is the object of the moral life is analogously rather than univocally common to human existence in different cultures and different periods. When the theory of analogy is extended from its speculative use in metaphysics to a practical use in ethics, obligations under natural law are seen to be analogously rather than univocally common. There are universal and necessary aspects of our human moral obligations but it is extremely difficult to capture these intelligibilities in univocal formulae which bind all humans in the same respect.

It is not commonly realized that a certain universality and necessity is implicit in the evolutionary approach to human obligation. However, evolutionary theorists generally think of evolution as an irreversible process. This process involves a certain necessity not only in man's present state but also in the future course of evolution. Evolution is not simply irreversible in the sense that it is statistically improbable that a sequence of gene mutations should reverse itself, but certain steps taken in evolution are irrevocable. Things may have proceeded differently on other worlds, but on earth rational animals carry within every cell of their bodies chromosomes and genes which took shape in the course of an evolution within the chordate phylum, with the result that humans have cognitive and appetitive experiences which are 
irrevocably determined by their mammal and primate ancestry. A complex of psycho-biological needs is present in man as a residue of his evolutionary past.

The realization that the principle in man which makes him capable of cultural evolution is more than organic has implications concerning universal and necessary obligations. Evolution continues in the human species chiefly in the area of society and culture, although the possibility of further organic evolution cannot be ruled out. The fact of technological progress is widely acknowledged. Technological advance, however, occurs in a social matrix and requires forms of cooperation and a syndrome of changes involving writing, metallurgy, urbanization, and political structures. ${ }^{34}$ If human culture has adaptive value and exists to fulfill human needs, then an evolution in culture and technology cannot proceed without repercussions in morality.

The state is a natural institution. Yet it did not always exist. Surely the rise of effective political organizations, making possible higher levels of spontaneity and self-motion in relation to our physical setting and other humans, must be considered progress in some absolute sense. It is progress measured by life as a self-moving process, as measured in the development of human potentialities and the increase of the scope of practical reason toward the willing of the good common to all mankind. To be sure, along with more opportunities to lead a fuller human life, there are also possibilities of greater moral evil. As I write, the continued existence of the human species is jeopardized by our present inability to devise effective world-wide institutions to handle problems common to all men on earth, problems such as nuclear warfare, the development of undeveloped countries, international cooperation in research and industry. The human situation is indeed precarious, but it is certain that only a being with superior moral capabilities can inflict the physical and moral damage now possible. This condition of grave risk and challenge contains seeds for the emergence of new levels of human cooperation, of love and justice and prudence, which will increase in man that human mode of participation in the eternal law which we call the natural moral law.

34. Evolution Apter Darwin, supta note 9, Vol. II, pp. 153-168; Vol. III, p. 228, pp. 221-224. 